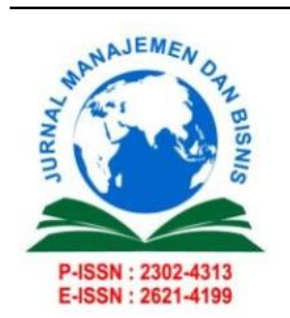

\title{
Jurnal Manajemen dan Bisnis
}

\author{
Vol. 10 , No. 1, Juni 2021, pp. 103- 120 \\ Sekolah Tinggi Iímu Ekonomi Indragiri (STIE-I) Rengat \\ https://journal.stieindragiri.ac.id/index.php/jmbi/issue/view/17
}

\section{THE EFFECT OF THE NATIONAL ECONOMIC RECOVERY PROGRAM ON MSME PRODUCTIVITY DURING THE COVID-19 PANDEMIC}

\author{
Khotim Fadhli'), Zuni Miftakhur Rohmah ${ }^{2)}$ \\ 1) 2) Faculty of Economics, Universitas K.H. A. Wahab Hasbullah \\ khotim@unwaha.ac.id ${ }^{1)}$, Zunimifta@gmail.com ${ }^{2)}$ \\ Submited: 2021.06.26 Reviewed: 2020.08.11 Accepted: 2021.08.27 \\ https://doi.org/10.34006/jmbi.v10i1.286
}

\begin{abstract}
This study aims to analyze the effect of the national economic recovery program (PEN) in Indonesia in an effort to increase productivity for MSME actors due to the Covid-19 pandemic. The economic sector, which has also been affected by the Covid-19 pandemic, has resulted in many MSMEs experiencing a decline in turnover, even going bankrupt. So the government makes programs through the national economic recovery policy (PEN) to overcome the problems faced by MSMEs. This research is a quantitative research, with the population in the study are all MSMEs in the Gudo Manik-Manik Center, Jombang Regency, which then determined a sample of 73 respondents using the slovin formula. The sampling technique used was probability sampling with the random sampling method, because taking all the population, namely MSME Gudo Manik-Manik Center, had the same opportunity to become respondents. Data was taken using a questionnaire. The research analysis used is multiple linear regression using SPSS 26. The results of the study state that, the tax incentive which is an economic recovery program (PEN) has no effect on the productivity of MSMEs during the COVID-19 pandemic at the Manik-Manik Gudo Jombang Center. Meanwhile, loan restructuring, which is an economic recovery program (PEN) has a significant impact on MSME productivity during the Covid-19 pandemic at the Gudo Manik-Manik Center. Simultaneously, tax incentives and loan restructuring, which are part of the economic recovery program (PEN) have a significant influence on the productivity of MSMEs during the Covid-19 pandemic at the Gudo Manik-Manik Center, Jombang.
\end{abstract}

Keyword : Tax Incentives, loan Restructuring, Productivity

\section{INTRODUCTION}

The spread of the corona virus, which is a type of virus that can cause diseases that can cause severe symptoms, such as middle east respiratory syndrome (Mers) and severe acute respiratory syndrome (SARS). The spread of this virus, which is massive and difficult to control, has led to an international determination that an extraordinary event or pandemic is occurring, which is called corona virus disease 2019 (Covid-19). The spread of the virus that resulted in the emergence of a new type of disease experienced by humans has never existed before. (Almuttaqi, 2020)

The spread of the corona virus also occurred in Indonesia, and the initial data found that there were positive Indonesian people infected with the corona virus was first reported on March 
2, 2020. Since then, the transmission of this corona virus has been increasingly massive and widespread in various regions in Indonesia. The transmission is known because there is direct contact that occurs in the community.

The massive spread of Covid-19 throughout Indonesia has increased the number of transmission of positive cases of Covid-19 in Indonesia. In response to the Covid-19 pandemic, the Indonesian government made a policy by starting to implement social restrictions, namely the implementation of activities that implement social distancing to avoid crowds. The social distancing policy that is applied will certainly have other impacts on other aspects, such as social and economic aspects. (Fadhli \& Fahimah, 2021)

The real impact that can be seen is the decline in household consumption or the weakening of people's purchasing power for all products. This resulted in shocks to sectors of the economy. The consumptive sector is one of the sectors that is most felt, which is also caused by the behavior of people who begin to limit activities outside the home. Given the large number of business sectors in Indonesia, which are micro, small and medium enterprises, a decline in people's purchasing power has resulted in a decrease in the turnover of business owners.

Jombang Regency is one of the areas that has felt the impact of the Covid-19 pandemic, as experienced by traders or business actors, especially MSMEs that are widely spread in Jombang, which eventually faltered in their production and marketing and caused traders or business owners to not be able to operate as usual. .

Many types of businesses or products are engaged in by MSMEs in Jombang Regency, one of which is beads whose business is in the Gudo Beads Center Jombang. Based on the findings in the field, there was a decline in productivity for the majority of business owners or bead traders at the Gudo Manik-Manik Center Jombang. MSME business turnover at the Gudo Manik-Manik Center Jombang has decreased drastically due to the impact of the Covid-19 pandemic. The declines varied, and of the 89 MSMEs in the Gudo Manik-Manik Center Jombang, the majority decreased to more than $50 \%$.

Table of percentage decline in turnover

\begin{tabular}{|c|c|c|c|c|}
\hline \multirow{2}{*}{$\begin{array}{c}\text { Number of } \\
\text { SMEs }\end{array}$} & \multicolumn{4}{|c|}{ Decrease in Business Turnover } \\
\cline { 2 - 5 } & $\mathbf{1 \%}-\mathbf{2 5 \%}$ & $\mathbf{2 6 \%}-\mathbf{5 0 \%}$ & $\mathbf{5 1 \%}-\mathbf{7 5 \%}$ & $\mathbf{7 6 \%} \mathbf{- 1 0 0 \%}$ \\
\hline 89 & 3 & 18 & 49 & 19 \\
\hline
\end{tabular}

Source: Data processed, 2021

This is one of the impacts that occurred due to the Covid-19 pandemic which made restrictions on community activities, so that the community, especially business owners in the micro sector, namely MSMEs experienced a decrease in sales turnover which also resulted in a decrease in the productivity of the MSMEs. When this is allowed to continue, the MSME sector which is one of the business sectors supporting the national economy will collapse because many MSMEs are out of business and will increase the number of unemployed in Indonesia.

The central government, as well as regional governments, certainly will not remain silent. So that other policies have emerged whose aim is to maintain the economic stability of the community due to the Covid-19 pandemic, because it is not yet known when it will end. It is known that there are two main focuses in handling the impact of the Covid-19 pandemic in 
Indonesia, namely focusing on health and on economic recovery. Thus, the allocation of the state budget and revenue is diverted more to these two sectors.

Finance Minister Sri Mulyani, in her presentation, gave a statement regarding the impact of the Covid-19 pandemic. Thus, the Covid-19 pandemic has had three major impacts on the Indonesian economy. First, this condition causes household consumption or people's purchasing power to decrease drastically. Second, this condition creates uncertainty which results in weakening investment. Third, this condition weakened exports and made the prices of oil, coal and CPO commodities fall. (Fadhli, Himmah, et al., 2021)

In the economic recovery sector, the Government makes policies by issuing stimulus to the public in the form of incentives as a form of handling the impact of the pandemic. These incentives are part of the National Economic Recovery Program or called PEN. Based on Government Regulation Number 23 of 2000, the National Economic Recovery Program (PEN) is a series of activities for national economic recovery which is part of the state financial policy implemented by the Government. The National Economic Recovery Program (PEN) aims to accelerate the handling of the Covid-19 pandemic.

In implementing the National Economic Recovery (PEN) program, the central government focuses its policies on business actors, especially micro sector businesses, namely MSMEs, and the community. These two elements are considered to play an important role in accelerating the economic recovery of the community. The realization of the MSME stimulus ceiling in the 2020 National Economic Recovery (PEN) program is Rp. 114.81 Trillion. This figure is equivalent to $96.7 \%$ of the total budget of 116.32 trillion. The funds were realized for interest subsidies, loan restructuring, and tax incentives. The stimulus for the National Economic Recovery (PEN) program given to MSMEs is a stimulus model that aims to strengthen MSME capital.

In the field of taxation, one of the strategies or programs in the National Economic Recovery (PEN) is the existence of a tax incentive policy. This tax incentive policy aims to help move the wheels of the country's economy which is experiencing a rapid decline due to the Covid-19 pandemic. The tax incentive policy is contained in the Minister of Finance Regulation (PMK) No. 86 of 2020, which is a revision of PMK No. 44 of 2020 concerning tax incentives for taxpayers affected by the covid-19 pandemic. The five tax incentive policies are PPh Article 21 incentives, PPh Article 22 imports, PPh Article 25 installments, MSME tax and VAT.

Based on PMK No. 44 of 2020, the government will bear the Final PPh of UMKM PP No. 23 of 2018 concerning income tax on income from businesses received or obtained by taxpayers who have a certain gross turnover until December 2020. The relief is given because the sector MSMEs contributed greatly to Indonesia's Gross Domestic Product (GDP), up to 61.7\% or around Rp. 8,952T out of a total of Rp. 14,837T in 2018. In addition, MSMEs also absorb up to $97 \%$ of the total workforce. (Indaryani et al., 2020)

According to(Indaryani et al., 2020), in his research entitled The Impact of Covid-19 and the Utilization of Tax Incentives on Business Continuity in MSMEs Weaving TrosoJepara stated that the use of tax incentives had a positive effect on business continuity. Another study conducted (Suprapto, 2013)on the effect of tax incentive policies on the productivity of the palm oil processing industry in the work area of the North Sumatra I Directorate General of Taxation 
office explained that the tax incentive policy had a direct and significant effect on the productivity of the palm oil processing industry.

However, in another study conducted (Hartono \& Setyowati, 2009)which aims to find information on the effect of the policy of providing tax incentives on the investment climate in the textile industry sector in Indonesia, especially those registered as taxpayers at the Four Foreign Investment Tax Service Office, mentions that the tax incentive policy is not significantly related to the investment climate of foreign investment companies in the textile industry sector.

In addition to tax incentives, national economic recovery policies or programs (PEN) are interest subsidies and loan restructuring. This is so that there will be additional capital owned by business owners, especially MSMEs so that they can be used as a support for the business they are running.

However, there is research that has been done by (Andriani, 2020) which states that productive business capital assistance does not have much effect on increasing Mustahik's income. in Makassar City. Meanwhile, another study conducted (Hasugian et al., 2016)stated that the addition of cash had a positive and partially significant effect on the business productivity of CV. Maryana Jaya in Muara Badak.

The existence of the National Economic Recovery (PEN) program in which one of the target sectors is MSMEs is a breath of fresh air that can be used as MSMEs in Indonesia to continue to survive during this Covid-19 pandemic. However, the PEN policies or programs also need to be reviewed, especially their impact on the MSME sector which is the target of the program.

From the results of the previous research above, it can also be used as a basis for the need for further studies in other areas related to the effect of the national economic recovery program (PEN) on the productivity of MSMEs in Jombang, particularly related to tax incentives and loan restructuring. So, it can be used as a comparison or one of the basis for determining the sustainability of the policy or program in the future, and the target of national economic recovery in Indonesia during the Covid-19 pandemic can be realized.

\section{THEORITICAL REVIEW}

\section{National Economic Recovery Program}

Based on Government Regulation Number 23 of 2000, the National Economic Recovery Program (PEN) is a series of activities for national economic recovery which is part of the state financial policy implemented by the Government. The National Economic Recovery Program (PEN) aims to accelerate the handling of the Corona Virus Disease 2019 (Covid-19) pandemic.

The National Economic Recovery Program (PEN) policy is a central government program implemented with the hope and objective of protecting, maintaining, and improving the economic capacity of actors and the community. The business actors in question are businesses in all sectors, especially the micro business sector, namely MSMEs that are trying to keep running their business during the Covid-19 pandemic. In implementing the National Economic Recovery (PEN) policy, the allocation of APBN funds that have been issued for this program amounted to Rp.692.2 Trillion. 
The National Economic Recovery Program (PEN) that supports the micro or MSME sector business world, including:

1) Interest subsidies. Funds for interest subsidies that are budgeted from the APBN are Rp. 34.15 Trillion

2) Tax Incentives. Funds for tax incentives that are budgeted from the APBN are Rp. 28.06 Trillion (PPh 21 DTP, Final PPh MSME DTP)

3) Loans for new working capital for SMEs. Funds for new working capital loans for MSMEs that are budgeted from the APBN are Rp. 6 Trillion.

\section{Tax Incentive}

The tax incentives that exist in (Saputra et al., 2020) defined according to UNCTAD (2003), are instruments that can reduce the tax burden of any party as part of a way to persuade taxpayers to be willing to invest in a particular project or sector. Tax incentives can also be referred to as a provision that provides benefits for a taxpayer or activity conditions that deviate from the normal provisions of the tax law. Tax spending refers to income losses incurred by the government by providing tax exemptions, providing tax deductions or tax allowances, tax credits, preferential tax rates or withholding tax payments made legally to any party in the economic sector.(Gravelle, 2013)

Tax is a transfer of wealth from the community to the state or the state treasury, which will later be used to finance routine expenditures, and the tax surplus will be used for public saving, which is the main source for financing public investment.(Resmi, 2013). Taxes imposed on the public are not only used to increase government income, but the existence of tax withdrawals to predetermined taxpayers is aimed at encouraging economic growth. In general, tax incentives are divided into four forms, including: (1) tax exemption (2) reduction from the tax base (3) reduction in tax rates (4) tax deferral.(Syanti \& Widyasari, 2020)

\section{Loan Restructuring}

Credit restructuring or loan is a financial term that is often used in terms of the banking sector, which aims to save credit that is experiencing problems. According to(Hasibuan, 2010), restructuring or rearrangement is a change in credit terms which can involve adding bank funds, converting part or all of arrears of interest into new loan principals, or converting part or all of them into bank participation or taking other partners to increase participation. Loan restructuring is one of the bank's programs, which is a means and effort of the bank in its repair activities. Its activities, in credit activities for debtors who have difficulty fulfilling their obligations.

The indicators in this study refer to the Decree of the Board of Directors of Bank Indonesia, namely: (1) lower interest rates; (2) Reduction of loan interest arrears; (3) Reduction of loan principal arrears; (4) Extension of credit period; (5) Addition of credit facilities; (6) takeover of debtor's assets in accordance with applicable regulations; (7) conversion of credit into temporary equity participation in debtor companies(Suartama et al., 2017)

\section{SMEs}

In Law Number 20, 2008, it is explained that micro, small and medium enterprises or MSMEs are trading businesses managed by business entities or individuals referring to productive economic businesses. According to (Fadhli \& Saraswati, 2021), there are several criteria for SMEs that must be understood, namely: 
1. Micro business, is a type of productive economic business owned by an entity or individual that has met the criteria in the applicable law.

2. Small business, is a type of independent productive economic business carried out by a business entity / individual that is not a subsidiary that is owned, controlled, or becomes a part either directly or indirectly of a medium or large business that has met the criteria in the law.

3. Medium business, is a type of productive economic business that stands alone, which is carried out by a business entity / individual that is not a subsidiary that is owned, controlled, or becomes a part either directly or indirectly of a small business or a large business with a total net worth or annual sales proceeds that have been regulated in the applicable law.

The grouping of Micro, Small and Medium Enterprises (MSMEs) according to Law Number 20, of 2008, MSMEs are divided into several category definitions (Widayanti et al., 2017).

1. The category of micro-enterprises refers to net worth, which is at most Rp. 50,000,000,(fifty million rupiah) which does not include land and buildings for business premises, or having annual sales results of a maximum of Rp. 300,000,000, - (three hundred million rupiah).

2. The category of small business can be seen from the entities that have the following criteria:

a. net worth starting from more than Rp. 50,000,000, - (fifty million rupiah), and the maximum wealth is Rp. 500,000,000.- (five hundred million rupiah), which does not include land and buildings for business premises;

b. has annual sales results of its business is more than Rp.300,000,000, - (three hundred million rupiah), up to a maximum of Rp. 2.500,000,000, - (two billion five hundred million rupiah).

3. The medium-sized business category can be seen based on business entities that have the following criteria:

a. net worth more than Rp. 500,000,000, - (five hundred million rupiah), up to a maximum of Rp. 10,000,000,- (ten billion rupiah), which does not include land and buildings for business premises;

b. have annual sales results of more than Rp. 2,500,000,000,- (two billion five hundred million rupiah), up to a maximum of Rp. 50,000,000,000,- (fifty billion rupiah

\section{Productivity}

Productivity is a comparison between the results or output produced, and also the amount of work expended or done to produce it, or in a more general and broad sense, namely the ratio between the desired satisfaction and the sacrifices made to get the desired result.(Ismail et al., 2021). Productivity is an interdisciplinary approach model useful for setting effective goals, for planning, for applying ways to increase productivity, for using resources efficiently, and for maintaining high quality. (Sinungan, 2003)

Productivity involves the integrated utilization of human resources (HR) and skills, capital goods, technology, management, information, energy, and other resources towards the development and improvement of living standards for the entire community, through the concept of total or universal productivity. Productivity is the level of efficiency in producing goods or services. Productivity directs how to use resources properly in producing goods.(Fadhli, 
Maghfiroh, et al., 2021). So the increase in productivity in a business is mainly related to three types of sources: (1) Capital, namely in the form of equipment, materials, land, and buildings; (2) Manpower; Management and organization. Muchdarsyah also conveyed the same thing (in Cahyono and Lestiyana, that the indicators of productivity are: (1) labor; (2) art and management science; (3) capital.

The conceptual framework can be reflected in the image below:

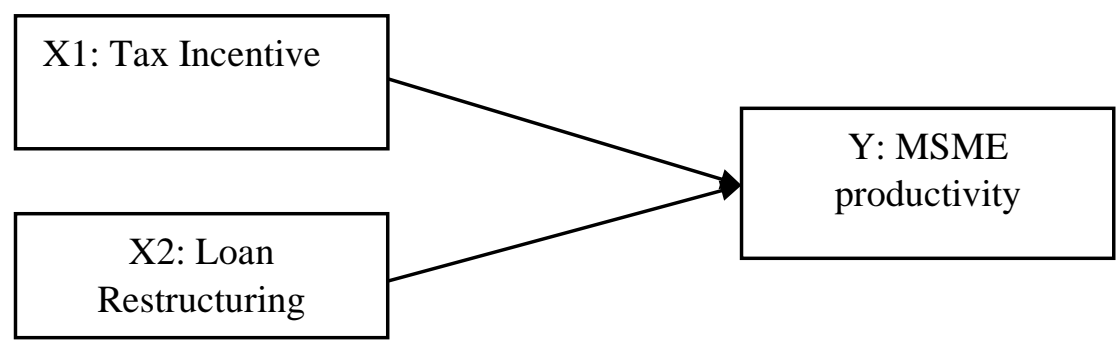

\section{RESEARCH METHODS}

This research is included in the type of quantitative research, because this research is presented with a display of numbers from the results of the SPSS 26 test. This is in accordance with the opinion of (Arikunto, 2010)which states that quantitative research is a research approach that is required to reveal numbers, ranging from of data collection, interpretation of the data, and the appearance of the results. According to (Sugiyono, 2016), quantitative research is a research method based on the philosophy of positivism, used to examine certain populations or samples. As in general, the sampling technique is done randomly, and data collection in quantitative research uses research instruments. Data analysis in quantitative research is quantitative / statistical in nature with the aim of testing the established hypothesis. The data was obtained from the results of the collection of questionnaires given to business actors or MSMEs in the Gudo Manik-Manik Center Jombang.

There are three variables in this study, namely two independent variables and one dependent variable. The independent variable of this research is tax incentive (X1) which consists of indicators: (1) tax exemption (2) reduction of tax base (3) reduction of tax rate (3) tax deferral and loan restructuring (X2) consists of indicators: ( 1) reduction in interest rates (2) reduction in loan interest arrears (3) reduction in loan principal arrears (4) extension of credit period (5) addition of credit facilities (6) withdrawal of debtor assets in accordance with applicable regulations (7) conversion of credit into equity participation while at the debtor company. While the dependent variable of this research is the productivity of MSMEs (Y) which consists of indicators: (1) labor (2) arts and management science (3) capital.

The population used in this study were all business actors or MSMEs in the Gudo ManikManik Center Jombang. The total population in the study was 89 MSMEs. While the number of samples in the study were 73 SMEs, which were obtained from calculations using the Slovin formula. The instruments used in the study were divided into structured question forms according to the variables through a questionnaire or questionnaire. The questionnaire used in this study is a closed questionnaire, while the answer model is based on a Likert scale model.

The data analysis technique in this study uses analytical techniques with multiple linear regression models. According to (Arikunto, 2010), multiple regression analysis is an analysis of 
the influence of the relationship between one dependent variable and two or more independent variables. To test the hypothesis, it is carried out using two test methods, namely the t test and the F test using the SPSS 26 analysis tool.

To avoid any discrepancy in the research results obtained, the classical assumption test is used which consists of several kinds of tests, namely normality, linearity, multicollinearity, autocorrelation, and heteroscedasticity tests. Furthermore, to determine the percentage of the influence of all independent variables on the value of the dependent variable. Researchers can see from the magnitude of the coefficient of determination. The magnitude of the coefficient of determination from 0 to 1 . The closer to 0 the magnitude of the coefficient of determination of a regression equation, the smaller the influence of all independent variables on the dependent variable.

\section{RESULTS AND DISCUSSION}

The bead center located in Gudo, Jombang Regency is a business center that sells various types and models of beads. The business center, which was inaugurated by the President of Indonesia during the leadership of Susilo Bambang Yudhoyono, has become a center for the bead trade in Jombang Regency and its surroundings. In this center, there are many MSMEs that carry out business processes, ranging from production, retail trade, to marketing outside the region, even abroad.

The existence of the Covid-19 pandemic which has led to many government policies related to social restrictions, including regional restrictions that have occurred in several regions, including other countries, has resulted in a decrease in the turnover of business owners or MSMEs in Indonesia, including MSMEs in the Manik-Manik Gudo Center. Jombang Regency.

The beading business in Plumbon Gambang Village, Gudo District, Jombang Regency, experienced a famine during the covid-19 pandemic, and some MSMEs even stopped operating. The reason is, the Covid-19 that spreads in Indonesia has resulted in restrictions on social activities which also result in the closure of access to tourism and transportation. This is very impactful for the bead craftsmen because most of the consumers from MSMEs in the Gudo Manik-Manik Center are in the tourism sector.

The tourism sector has also experienced a significant decline due to the covid-19 pandemic(Jannah et al., 2021), this is due to a decrease in the number of tourists or visitors at tourist attractions. And the decline in the tourism sector certainly has a relationship with the decline in turnover of business actors whose products are sold in several tourist locations, such as beads from Gudo Manik-Manik Center Jombang. Before the pandemic, there were many sales of beads which were distributed to several tourist attractions in Jombang Regency and several cities outside Jombang, for example Surabaya, Jakarta, Jogjakarta, Kalimantan, and even exported abroad. However, the impact of the Covid-19 pandemic has made product orders experience a drastic decline from any region.

Table of percentage decline in turnover

\begin{tabular}{|c|c|c|c|c|}
\hline \multirow{2}{*}{$\begin{array}{c}\text { Number of } \\
\text { SMEs }\end{array}$} & \multicolumn{4}{|c|}{ Decrease in Business Turnover } \\
\cline { 2 - 5 } & $\mathbf{1 \%} \mathbf{- 2 5 \%}$ & $\mathbf{2 6 \%}-\mathbf{5 0 \%}$ & $\mathbf{5 1 \%}-\mathbf{7 5 \%}$ & $\mathbf{7 6 \%}-\mathbf{1 0 0 \%}$ \\
\hline 89 & 3 & 18 & 49 & 19 \\
\hline
\end{tabular}

Source: Data processed, 2021 
There are 89 business owners or SMEs in the Gudo Manik-Manik Center Jombang. Of the 89 MSMEs, 49 MSMEs experienced a decline in turnover ranging from 51\% to $75 \%$. There were 19 MSMEs that experienced a $76 \%$ to $100 \%$ decrease in turnover, which means that there were some MSMEs that had no turnover at all during the Covid-19 pandemic and closed their businesses. Meanwhile, it is known that there are 18 MSMEs that experienced a decrease in turnover ranging from $26 \%$ to $50 \%$. And what is quite surprising is that there are only 3 MSMEs whose turnover declines ranging from $1 \%$ to $25 \%$.

The decline in turnover is known for three reasons. First, because of the cessation of ordering products from MSMEs at the Gudo Manik-Manik Center from most of the customers. Second, because some outlets or shops selling beads outside the city were closed due to social restrictions. Third, the less money from the sale that comes in makes the use of existing business capital to be used to maintain the business, one of which is through a very drastic decrease in selling prices.

Based on the findings in the field, of the 73 respondents who were sampled, information regarding the characteristics of the respondents, including gender and age, was explored. Based on gender, the majority of business owners are male with 69 or $94 \%$ of the total respondents. Meanwhile, there are 4 female business owners or $4 \%$ of the total respondents. Based on age, it was found that there were 46 business owners who were more than 51 years old or $63 \%$ of the total sample studied.

Table of Age of Business Owners at Gudo Manik-Manik Center

\begin{tabular}{|c|c|c|}
\hline Age of Business owner & Total & Percentage \\
\hline$\leq 30$ years & 1 & $1 \%$ \\
\hline $31-40$ years & 6 & $8 \%$ \\
\hline $41-50$ years & 20 & $27 \%$ \\
\hline$\geq 51$ years & 46 & $63 \%$ \\
\hline
\end{tabular}

Source: Data processed, 2021

In the questions asked to the respondents, a validity test was carried out, the results of which were: Item r Calculate $r$ Table Description

Table of Tax Incentive Variable Validity Test Results (X1)

\begin{tabular}{|c|c|c|c|c|}
\hline No & Item & r Calculate & r Table & Description \\
\hline 1 & $\mathrm{X} 1.1$ & 0,191 & 0,227 & Invalid \\
\hline 2 & $\mathrm{X} 1.2$ & 0,506 & 0,227 & Valid \\
\hline 3 & $\mathrm{X} 1.3$ & 0,155 & 0,227 & Invalid \\
\hline 4 & $\mathrm{X} 1.4$ & 0,613 & 0,227 & Valid \\
\hline 5 & $\mathrm{X} 1.5$ & 0,280 & 0,227 & Valid \\
\hline 6 & $\mathrm{X} 1.6$ & 0,480 & 0,227 & Valid \\
\hline 7 & $\mathrm{X} 1.7$ & 0,142 & 0,227 & Invalid \\
\hline 8 & $\mathrm{X} 1.8$ & 0,500 & 0,227 & Valid \\
\hline 9 & $\mathrm{X} 1.9$ & 0,539 & 0,227 & Valid \\
\hline 10 & $\mathrm{X} 1.10$ & 0,432 & 0,227 & Valid \\
\hline 11 & $\mathrm{X} 1.11$ & 0,338 & 0,227 & Valid \\
\hline 12 & $\mathrm{X} 1.12$ & 0,701 & 0,227 & Valid \\
\hline
\end{tabular}




\begin{tabular}{|c|c|c|c|c|}
\hline 13 & X1.13 & 0,520 & 0,227 & Valid \\
\hline 14 & X1.14 & 0,525 & 0,227 & Valid \\
\hline 15 & X1.15 & 0,631 & 0,227 & Valid \\
\hline
\end{tabular}

Source: Data processed, 2021

Loan Restructuring Variable Validity Test Results (X2)

\begin{tabular}{|c|c|c|c|c|}
\hline No & Item & r Calculate & r Table & Description \\
\hline 1 & $\mathrm{X} 1.1$ & 0,191 & 0,227 & Invalid \\
\hline 2 & $\mathrm{X} 1.2$ & 0,506 & 0,227 & Valid \\
\hline 3 & $\mathrm{X} 1.3$ & 0,155 & 0,227 & Invalid \\
\hline 4 & $\mathrm{X} 1.4$ & 0,613 & 0,227 & Valid \\
\hline 5 & $\mathrm{X} 1.5$ & 0,280 & 0,227 & Valid \\
\hline 6 & $\mathrm{X} 1.6$ & 0,480 & 0,227 & Valid \\
\hline 7 & $\mathrm{X} 1.7$ & 0,142 & 0,227 & Invalid \\
\hline 8 & $\mathrm{X} 1.8$ & 0,500 & 0,227 & Valid \\
\hline 9 & $\mathrm{X} 1.9$ & 0,539 & 0,227 & Valid \\
\hline 10 & $\mathrm{X} 1.10$ & 0,432 & 0,227 & Valid \\
\hline 11 & $\mathrm{X} 1.11$ & 0,338 & 0,227 & Valid \\
\hline 12 & $\mathrm{X} 1.12$ & 0,701 & 0,227 & Valid \\
\hline 13 & $\mathrm{X} 1.13$ & 0,520 & 0,227 & Valid \\
\hline 14 & $\mathrm{X} 1.14$ & 0,525 & 0,227 & Valid \\
\hline 15 & $\mathrm{X} 1.15$ & 0,631 & 0,227 & Valid \\
\hline
\end{tabular}

Source: Data processed, 2021

Productivity Variable Validity Test Results (Y)

\begin{tabular}{|c|c|c|c|c|}
\hline No & Item & R Calculate & r Table & Description \\
\hline 1 & $\mathrm{X} 1.1$ & 0,688 & 0,227 & Valid \\
\hline 2 & $\mathrm{X} 1.2$ & 0,620 & 0,227 & Valid \\
\hline 3 & $\mathrm{X} 1.3$ & 0,541 & 0,227 & Valid \\
\hline 4 & $\mathrm{X} 1.4$ & 0,515 & 0,227 & Valid \\
\hline 5 & $\mathrm{X} 1.5$ & 0,162 & 0,227 & Invalid \\
\hline 6 & $\mathrm{X} 1.6$ & 0,140 & 0,227 & Invalid \\
\hline 7 & $\mathrm{X} 1.7$ & 0,418 & 0,227 & Valid \\
\hline 8 & $\mathrm{X} 1.8$ & 0,043 & 0,227 & Invalid \\
\hline 9 & $\mathrm{X} 1.9$ & 0,530 & 0,227 & Valid \\
\hline 10 & $\mathrm{X} 1.10$ & 0,321 & 0,227 & Valid \\
\hline 11 & $\mathrm{X} 1.11$ & 0,338 & 0,227 & Valid \\
\hline 12 & $\mathrm{X} 1.12$ & 0,297 & 0,227 & Valid \\
\hline 13 & $\mathrm{X} 1.13$ & 0,501 & 0,227 & Valid \\
\hline 14 & $\mathrm{X} 1.14$ & 0,551 & 0,227 & Valid \\
\hline 15 & $\mathrm{X} 1.15$ & 0,308 & 0,227 & Valid \\
\hline
\end{tabular}

Source: Data processed, 2021

Based on the table above, the results of the validity test show that the value of the product moment correlation coefficient ( $\mathrm{r}$ count) of 45 statement items, there are 36 statements that are greater than $r$ table (0.227), which means it shows that 36 statements on the incentive instrument 
taxes, loan restructuring, and productivity are valid. So it was decided that 9 items of invalid statements were not used in extracting information to respondents.

The results of the reliability test also show that the instruments of tax incentives, loan restructuring, and productivity which consist of 45 statements have a Cronbach Alpha coefficient greater than 0.600 which means that the instruments used in the variables of tax incentives, loan restructuring, and productivity are reliable.

The regression model from the results of this analysis is $\mathrm{Y}=29.388+0.047 \mathrm{X} 1+0.306$ $\mathrm{X} 2+\mathrm{e}$ where the coefficient constant $(B 0=29.388)$ indicates that when the respondent's answer value is 0 then the respondent's answer value regarding MSME productivity is 29.388. The tax incentive regression coefficient $(B 1=0.047)$ indicates that each respondent's answer value regarding tax incentives is 1 unit, it will increase the value of the loan restructuring regression coefficient $(\beta 2=0.306)$ indicating that the respondent's answer regarding loan restructuring is 1 unit, it will increase the value of the respondent's answer. regarding the productivity of MSMEs is 0.306 .

\section{Picture of PP Plot Normality Test Results}

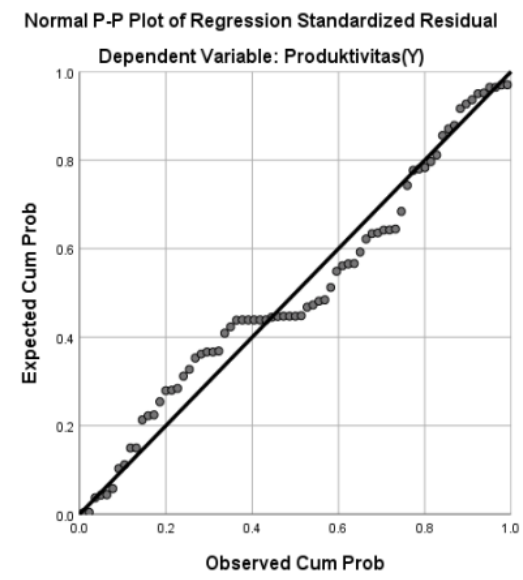

Source: Data processed, 2021

The results of the normality test using the PP Plot show that the data moves along a diagonal linear line, so it can be concluded that in general the data used is normally distributed and meets the assumption of normality.

Multicollinearity Test Result

\begin{tabular}{|c|c|c|c|c|c|c|c|c|}
\hline \multicolumn{9}{|c|}{ Coefficients $^{\mathrm{a}}$} \\
\hline & & \multicolumn{2}{|c|}{$\begin{array}{l}\text { Unstandardized } \\
\text { Coefficients }\end{array}$} & \multirow{2}{*}{$\begin{array}{c}\text { Standardized } \\
\text { Coefficients } \\
\text { Beta }\end{array}$} & \multirow[b]{2}{*}{$\mathrm{T}$} & \multirow[b]{2}{*}{ Sig. } & \multicolumn{2}{|c|}{ Collinearity Statistics } \\
\hline \multicolumn{2}{|c|}{ Model } & $B$ & Std. Error & & & & Tolerance & VIF \\
\hline \multirow[t]{3}{*}{1} & (Constant) & 29.388 & 3.461 & & 8.492 & .000 & & \\
\hline & InsentifPajak(X1) & .047 & .049 & .093 & .960 & .340 & .998 & 1.002 \\
\hline & $\begin{array}{l}\text { RestrukturisasiPinjaman } \\
\text { (X2) }\end{array}$ & .306 & .051 & .585 & 6.054 & .000 & .998 & 1.002 \\
\hline
\end{tabular}

Source: Data processed, 2021 
The results of multicollinearity using VIF have also been met, so that there are no symptoms of multicollinearity in this study.

Picture of Heteroscedasticity Test Results

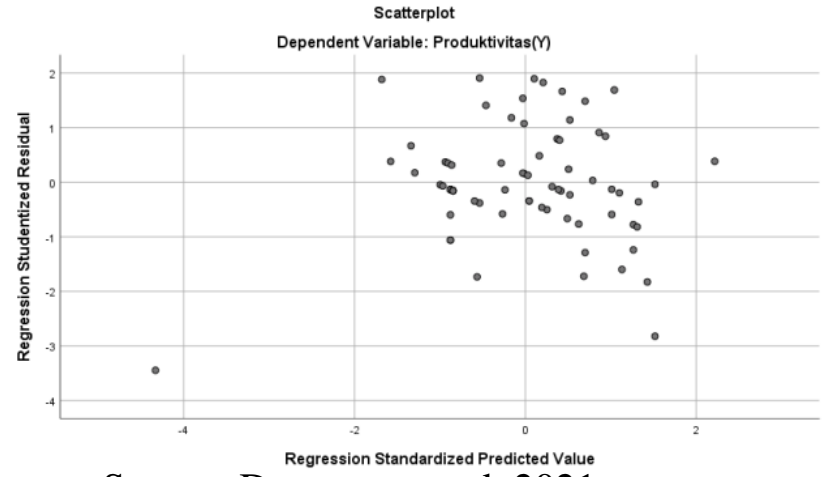

Source: Data processed, 2021

The results of the heteroscedasticity test can also be seen on the scatterplot where the points are spread out and do not form a certain pattern. Thus, it can be concluded that there is no heteroscedasticity in the regression model.

Tabel R Square

\begin{tabular}{|l|c|r|r|c|}
\hline \multicolumn{5}{|c|}{ Hasil Koefisien determinasi } \\
\hline Model & $\mathrm{R}$ & R Square & $\begin{array}{c}\text { Adjusted R } \\
\text { Square }\end{array}$ & $\begin{array}{c}\text { Std. Error of the } \\
\text { Estimate }\end{array}$ \\
\hline 1 & $.589^{\mathrm{a}}$ & .347 & .328 & 2.207 \\
\hline
\end{tabular}

Source: Data processed, 2021

Coefficient value $(\mathrm{R} 2=0.347)$. This means that the effect on the productivity of MSMEs is explained at $34.7 \%$ by tax incentives and loan restructuring, while the effect on other productivity of $65.3 \%$ is explained by other factors.

\section{The Effect of Tax Incentives on MSME Productivity}

Based on the results of the analysis table, it can be seen that the results of the tax incentive variable are known that $\mathrm{t}$ count $=0.960<1.666 \mathrm{p}=0.340>=0.05$, which means that the analysis shows that tax incentives have no effect on MSME productivity.

t test results table

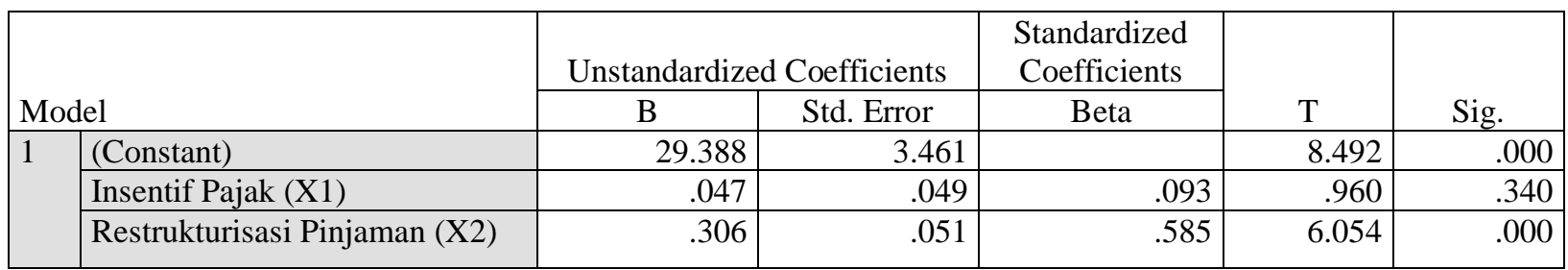

Source: Data processed, 2021

Based on these results, it shows that the tax incentive variable shows negative results and has no effect on the productivity of MSMEs in the Gudo Manik-Manik Center Jombang. The results of this study are different from previous research conducted by (Suprapto, 2013)regarding 
the effect of tax incentive policies on the productivity of the palm oil processing industry in the work area of the Regional Office of the Directorate General of Taxes, North Sumatra I. The result is that tax incentive policies have a direct and significant effect on productivity. palm oil processing industry.

In addition, this study is also different from the research conducted (Indaryani et al., 2020)which explains that the use of tax incentives has a positive effect on business continuity. The use of MSME PPh borne by the government which was extended until December 2020 turned out to have a major impact on the sustainability of the Troso Jepara Weaving MSME business because MSME actors do not need to pay taxes.

The difference in the results of the research obtained at the Gudo Manik-Manik Center Jombang is because there are several findings in the field indicating that there are several reasons that cause the tax incentives to not affect the productivity of MSMEs in the Gudo Manik-Manik Center Jombang. Some of these factors are; first, because the covid-19 pandemic caused a decrease in turnover in the beads business at the Gudo Manik-Manik Center Jombang. The Covid-19 pandemic has had a tremendous impact on the Indonesian economy, especially for MSMEs, as experienced by MSME business actors at the Gudo Manik-Manik Center Jombang.

The Covid-19 pandemic which is currently endemic has made a policy of limiting social activities so that the distribution of the products they market is also hampered. In addition, the restrictions on social activities have made many shops outside the city of Jombang that sell bead products from the Gudo Manik-Manik Center closed, including tourist sites. Thus, resulting in a decrease in business turnover, and the demand for beads fell drastically.

It is known that before the Covid-19 pandemic, beaded products were distributed outside the city and even penetrated abroad. However, during this Covid-19 pandemic, product distribution cannot be carried out. It is known that MSME actors at the Gudo Manik-Manik Center Jombang experienced a decline in turnover due to the Covid-19 pandemic. This is the reason SMEs do not pay their taxes.

Second, the reason that tax incentives do not affect the productivity of MSMEs at the Gudo Manik-Manik Center Jombang is the lack of awareness of MSME actors in paying taxes. This is motivated by the assumption of MSME actors, that taxes are a burden they must pay. Especially during this Covid-19 pandemic, business turnover has decreased.

Third, the reason that tax incentives do not affect the productivity of MSMEs during the Covid-19 pandemic is the tax system which is considered complicated by MSME actors at the Gudo Manik-Manik Center Jombang. Tax services during the pandemic are carried out online by the Directorate General of Taxes, and this is considered difficult for MSME actors, the majority of whom are over 51 years of age.

The tax procedures implemented by the Directorate General of Taxes can also cause MSME actors in the Gudo Manik-Manik Center Jombang not to pay taxes. These reasons mean that there is no effect of tax incentives on MSME productivity during the Covid-19 pandemic. Thus, the tax incentive program in the national economic recovery (PEN) policy during the Covid-19 pandemic is currently still considered less than optimal in increasing productivity, especially for MSMEs at the Gudo Manik-Manik Center Jombang. 


\section{The Effect of Loan Restructuring on MSME Productivity}

Based on the results of the previous t-test analysis table, it can be seen that the results of the loan restructuring variable are known that $t$ count $=6.054>1.666=0.00<=0.05$, which means that the analysis shows that the loan restructuring variable has a significant effect on MSME productivity. The results of the analysis show that loan restructuring has shown positive results and has an effect on the productivity of MSMEs during the Covid-19 pandemic at the Gudo Manik-Manik Center, Jombang.

Loan restructuring has a positive and significant impact on the productivity of MSMEs at the Gudo Manik-Manik Center because there are several factors that can have a positive influence on loan restructuring in the national economic recovery policy or program (PEN) on MSME productivity. First, there is an extension of time in paying loans for MSMEs. The loan restructuring policy was provided by the government through the Financial Services Authority (OJK) with the aim of keeping cash flow or capital turnover for MSMEs running and surviving despite the impact of the Covid-19 pandemic. From the findings in the field, delays in loan payments have helped MSME actors at the Gudo Manik-Manik Center in reducing the burden felt due to the impact of the Covid-19 pandemic. The existence of a policy of delaying loan payments is welcomed because it can make business continuity run even though there are many obstacles that are being experienced.

Second, the addition of credit facilities, which is a banking policy and subsequently provided through the Financial Services Authority (OJK). The addition of credit facilities is meant by the existence of loan offers through banks which are sought by the government to MSME actors at the Gudo Manik-Manik Center Jombang. At least there are several banks that are part of the government's cooperation in realizing the addition of loan restructuring facilities.

Third, the reduction of interest in loans. The reduction in interest on loans provided in the national economic recovery program (PEN) has allowed MSME actors at the GudoManik Center Jombang to get additional working capital without worrying too much about the interest expense. The existence of loan restructuring can be one of the solutions for business actors in MSMEs at the Gudo Manik-Manik Center to increase their business capital so that they can survive during the Covid-19 pandemic.

The results of this study are similar to research conducted by (Christiawan \& Azizah, 2018)which results in the addition of capital having a positive and significant effect on tobacco productivity in Panji Village and Pemaron Village in Buleleng Regency. Including research from (Hasugian et al., 2016)which explains that cash has a positive and partially significant effect on productivity so that there is an additional effect of working capital on company productivity $\mathrm{CV}$. Maryana Jaya in Muara Badak.

This is very necessary because business capital is very supportive of the productivity of MSMEs, because production activities can also run with the capital used in purchasing production materials, paying for labor, and other needs and needs. Thus, the loan restructuring program in the national economic recovery (PEN) policy during the Covid-19 pandemic is currently considered to have been maximal enough and hit in increasing productivity, especially for MSMEs in the Gudo Manik-Manik Center Jombang. 


\section{Simultaneous Effects of Tax Incentives and Loan Restructuring on MSME Productivity}

Based on the analysis table $\mathrm{F}$ test, it shows that there is a significant effect between tax incentives and loan restructuring together on the productivity of MSMEs in the Gudo ManikManik Center Jombang, because it is known that F count 18.571 > F table 3.13, p 0.000 < $=0.05$. This shows that the simultaneous change of tax incentives and loan restructuring will significantly change the productivity of MSMEs.

F Test Results Table

\begin{tabular}{|l|l|r|r|r|r|r|}
\hline \multicolumn{2}{|l|}{ Model } & $\begin{array}{c}\text { Sum of } \\
\text { Squares }\end{array}$ & Df & Mean Square & F & Sig. \\
\hline \multirow{2}{*}{1} & Regression & 180.870 & 2 & 90.435 & 18.571 & $.000^{\mathrm{b}}$ \\
\cline { 2 - 8 } & Residual & 340.883 & 70 & 4.870 & & \\
\cline { 2 - 8 } & Total & 521.753 & 72 & & & \\
\hline
\end{tabular}

Source: Data processed, 2021

Based on these results, that together, tax incentives and loan restructuring have an effect on the productivity of MSMEs. The findings in the field show that there needs to be collaboration between the two policies that are given so that they can have an effect if they are carried out simultaneously.

The national economic recovery policy (PEN) aimed at the government towards MSMEs in order to stabilize economic conditions is also a form of attention given to help the community due to the Covid-19 pandemic which has an impact on the economic sector. The National Economic Recovery Program (PEN), which includes tax incentives and loan restructuring together, is considered quite good, which means that the loan restructuring program in the national economic recovery policy (PEN) during the Covid-19 pandemic is currently considered to have been completed. quite maximal and impactful in increasing productivity, especially for MSMEs in the Gudo Manik-Manik Center Jombang.

\section{CONCLUSION}

Research that uses primary data or data collected directly by distributing questionnaires to 73 respondents of MSME actors at the Gudo Manik-Manik Center, the following conclusions are obtained:

1. The tax incentive which is an economic recovery program (PEN) has no effect on the productivity of MSMEs during the Covid-19 pandemic at the Gudo Manik-Manik Center Jombang. This is because; (a) the covid-19 pandemic caused a decrease in turnover in the beads business at the Gudo Manik-Manik Center Jombang; (b) lack of awareness of MSME actors in paying taxes; (c) the tax system which is considered complicated by MSME actors at the Gudo Manik-Manik Center Jombang.

2. Loan restructuring, which is an economic recovery program (PEN) has a significant impact on MSME productivity during the Covid-19 pandemic at the Gudo Manik-Manik Center. This is because; (a) there is an extension of time in repaying loans for MSMEs; (b) additional credit facilities; (c) interest reduction in loans from MSME actors at the Gudo Manik-Manik Center. The existence of a loan restructuring policy for MSMEs helps in capital. 
3. Simultaneously, tax incentives and loan restructuring as part of the economic recovery program (PEN) have a significant impact on MSME productivity during the Covid-19 pandemic at the Gudo Manik-Manik Center Jombang.

\section{Research Limitations}

There are some limitations experienced and can be several factors that can be paid more attention to future researchers in order to further refine their research because this research certainly has shortcomings that need to be improved in future studies. Some of the limitations in this study, among others:

1. The number of respondents who are only 79 MSMEs in the Gudo Manik-Manik Center Jombang, of course, is still insufficient to describe the actual situation at the national level.

2. The object of research is only focused on two national economic recovery programs, namely tax incentives and loan restructuring, which are only a small part of several national economic recovery programs or policies during the Covid-19 pandemic.

\section{Upcoming Research Agenda}

For future research, it will be carried out using a wider variety of variables with a larger and more even population and sample. So it is hoped that the results of the study can obtain clearer and more complete information on the impact or influence of the national economic recovery program for MSMEs in Indonesia.

\section{Recommended Research Results}

Recommendations that need to be conveyed from the results of this study include:

1. The government needs to conduct socialization directly and more frequently in the MSME sector, so that the knowledge and awareness of MSME actors regarding tax payment compliance can increase. MSME actors are willing to take advantage of MSME tax incentives and the sustainability of MSMEs is maintained

2. The Financial Services Authority (OJK) pays more attention to MSMEs during the Covid-19 pandemic, by providing more credit or loan relaxation / relaxation and a policy of delaying MSME loan payments. Loan restructuring is expected to help MSMEs to reduce the burden caused by the Covid-19 pandemic.

3. MSME actors should make more use of and maximize the national economic recovery program, be it tax incentives, loan restructuring, and other programs provided by the government in order to be able to survive the Covid-19 pandemic.

\section{BIBLIOGRAPHY}

Almuttaqi, A. I. (2020). The Omnishambles of COVID-19. THC Insights No. 13, The Habibie Center.

Andriani, A. (2020). Pengaruh Bantuan Modal Usaha Produktif terhadap Peningkatan Pendapatan Mustahik Pada Badan Amil Zakat Nasional (BAZNAS) Kota Makassar. Universitas Negeri Makasar.

Arikunto, S. (2010). Prosedur Penelitian Suatu Pendekatan Pratik. Rineka Cipta.

Christiawan, P. I., \& Azizah, N. Y. (2018). Pengaruh Penambahan Modal Terhadap 
Produktivitas Pertanian Tembakau Di Kabupaten Buleleng. Jurnal Pendidikan Geografi, 23(2), 68-77.

Fadhli, K., \& Fahimah, D. A. N. (2021). PENGARUH PENDAPATAN, PENDIDIKAN, DAN GAYA HIDUP TERHADAP KESEJAHTERAAN KELUARGA PENERIMA MANFAAT (KPM) BANTUAN SOSIAL COVID-19. JURNAL EDUCATION AND DEVELOPMENT, 9, 3. https://doi.org/https://doi.org/10.37081/ed.v9i3.2770

Fadhli, K., Himmah, S. R., \& Taqiyuddin, A. (2021). ANALISIS PERUBAHAN POLA KONSUMSI MASYARAKAT PENERIMA BANTUAN SOSIAL PADA MASA PANDEMI COVID-19. JURNAL EDUCATION AND DEVELOPMENT, 9(3), 110-117. https://doi.org/https://doi.org/10.37081/ed.v9i3.2777

Fadhli, K., Maghfiroh, V. F., \& Munawaroh, S. (2021). PENGARUH PEMANFAATAN ECOMMERCE TERHADAP PENINGKATAN PENJUALAN PRODUK UMKM DI KABUPATEN JOMBANG PADA MASA PANDEMI COVID-19. JPEKBM, 5(1). https://doi.org/https://doi.org/10.32682/jpekbm.v5i1.1978

Fadhli, K., \& Saraswati, U. (2021). Manajemen Keuangan Usaha Mikro Kecil Dan Menengah. Lima Aksara.

Gravelle, J. (2013). Corporate Tax Incidence: Review of General Equilibrium Estimates and Analysis. National Tax Journal, 66(1), 185-214.

Hartono, M. E., \& Setyowati, M. S. (2009). Hubungan Insentif Pajak dengan Iklim Investasi bagi Perusahaan Penanaman Modal Asing di Sektor Industri Tekstil di Indonesia. BISNIS \& BIROKRASI : Jurnal Ilmu Administrasi Dan Organisasi.

Hasibuan, M. S. P. (2010). Manajemen Sumber Daya Manusia. PT. Bumi Aksara.

Hasugian, L., Lau, E. A., \& Heriyanto. (2016). PENGARUH MODAL KERJA TERHADAP PRODUKTIVITAS PERUSAHAAN CV. MARYANA JAYA DI MUARA BADAK. Universitas 17 Agustus 1945 Samarinda.

Indaryani, M., Budiman, N. A., \& Mulyani, S. (2020). Dampak Covid-19 dan Pemanfaatan Insentif Pajak terhadap Keberlangsungan Usaha pada UMKM Tenun Troso Jepara. JURNAL MANAJEMEN DAN KEUANGAN, 9(3).

Ismail, A. N., Azzahro, S., Fadhli, K., \& Ni, A. (2021). Sustainability of Batik Sekar Jati Star Jombang Business in Building Creative Economy in The New Normal Era. 1(1), 1-4. https://ejournal.unwaha.ac.id/index.php/jurnal_penelitian/article/view/1374

Jannah, L. A., Rahmatika, A. N., Ismail, A. N., \& Fadhli, K. (2021). Manajemen Strategi Pengembangan Halal Tourism di Jombang. REVENUE: Jurnal Ekonomi Pembangunan Dan Ekonomi Syariah, 04(01), 14-23. https://ejournal.stieba.ac.id/index.php/revenue/article/view/32/20

Resmi, S. (2013). Perpajakan, Teori dan Kasus. Salemba empat.

Saputra, R., Meivira, F., Tingkat, P., Pemilik, P., Akuntansi, P., Persepsi, D. A. N., Saputra, R., \& Meivira, F. (2020). Pengaruh Tingkat Pendidikan Pemilik, Praktik Akuntansi Dan Persepsi Atas Insentif Pajak Terhadap Kepatuhan Pajak Umkm. Jurnal EMBA: Jurnal Riset Ekonomi, Manajemen, Bisnis Dan Akuntansi, 8(4), 1069-1079. https://doi.org/10.35794/emba.v8i4.31308 
Sinungan, M. (2003). Produktivitas Apa dan Bagaimana. PT. Bumi Aksara.

Suartama, I. W., Sulindawati, N. L. G., \& Herawati, N. T. (2017). Analisis Penerapan Restrukturisasi Kredit Dalam Upaya Penyelamatan Non Performing Loan (NPL) Pada PT BPR Nusamba Tegallalang. JIMAT (Jurnal Ilmiah Mahasiswa Akuntansi) Undiksha, 8(2).

Sugiyono. (2016). Metode Penelitian Kuantitatif, Kualitatif dan R\&D. Alfabeta.

Suprapto, A. (2013). Pengaruh Kebijakan Insentif Pajak Terhadap Produktivitas Industri Pengolahan Kelapa Sawit Di Wilayah Kerja Kantor Wilayah Direktorat Jenderal Pajak Sumatera Utara I. SEKOLAH PASCASARJANA UNIVERSITAS SUMATERA UTARA.

Syanti, D., \& Widyasari, N. (2020). Pengaruh Insentif Pajak, Tarif Pajak, Sanksi Pajak Dan. Jurnal Ekonomika Dan Manajemen, 9(2), 108-124.

Widayanti, R., Damayanti, R., \& Marwanti, F. (2017). Pengaruh Financial Literacy Terhadap Keberlangsungan Usaha (Business Sustainability) Pada Umkm Desa Jatisari. Jurnal Ilmiah Manajemen \& Bisnis, 18(2), 153. https://doi.org/10.30596/jimb.v18i2.1399 